\title{
Glazed PVT Collector with Polysiloxane Encapsulation of PV Cells: Performance and Economic Analysis
}

\author{
Tomas Matuska, ${ }^{1}$ Borivoj Sourek, ${ }^{2}$ Vladimir Jirka, ${ }^{2}$ and Nikola Pokorny ${ }^{2}$ \\ ${ }^{1}$ Faculty of Mechanical Engineering, Czech Technical University, Technicka 4, 16607 Prague, Czech Republic \\ ${ }^{2}$ University Centre of Energy Efficient Buildings, Czech Technical University, Trinecka 1024, 27343 Bustehrad, Czech Republic \\ Correspondence should be addressed to Tomas Matuska; tomas.matuska@fs.cvut.cz
}

Received 4 September 2015; Accepted 11 October 2015

Academic Editor: Xudong Zhao

Copyright (c) 2015 Tomas Matuska et al. This is an open access article distributed under the Creative Commons Attribution License, which permits unrestricted use, distribution, and reproduction in any medium, provided the original work is properly cited.

\begin{abstract}
Development of a new concept of glazed PVT collector based on temperature resistant polysiloxane encapsulation material is presented together with the results from experimental testing and modelling. Performance and economic analysis in 4 different European climates has been done to derive the competitive price of the PVT collector concepts with main focus on the glazed PVT collector under development. Results have shown that specific market price 400 to $500 \mathrm{EUR} / \mathrm{m}^{2}$ for the glazed PVT collector should not be exceeded in order to become competitive with conventional combination of photothermal and photovoltaic collectors.
\end{abstract}

\section{Introduction}

Solar photovoltaic-thermal (PVT) liquid collectors represent a new technology on the market which combines the electricity and heat generation from the same receiving surface in one device. The hybrid PVT collectors provide both heat and electricity, while the heat generation is several times higher than the electricity. Through the solar electricity and heat cogeneration, the total energy output per unit collector area can be higher than the outputs of conventional photovoltaic (PV) module and photothermal (PT) collector placed and operated separately with the equal total area $[1,2]$. Such feature could be effectively used in the building applications with high and constant use of thermal energy during the year but with the limited roof area, for example, DHW in the multifamily buildings and block of flats, or in the solar active houses with high solar fraction, for example, self-sufficient houses with a seasonal storage.

Because of the mature and cheap PV manufacturing process, the PVT collectors available on the market are based on standard PV laminates from ethylene-vinyl-acetate (EVA) compound. The hybrid PVT collectors based on EVA encapsulant are mainly offered as the unglazed ones so far with a poor thermal performance for usual solar thermal applications in buildings. Despite this fact, the market price of unglazed hybrid PVT liquid collectors achieves high level in comparison with standard glazed solar thermal collectors and PV modules. To improve the thermal performance the glazed PVT collector design has been developed [3] based on high performance components (fractal absorber, antireflection coatings, etc.). Stagnation temperature in glazed PVT solar collectors could reach 120 to $180^{\circ} \mathrm{C}$ and this fact reveals the main drawback of EVA copolymer application as an encapsulant of PV cells. Application of EVA laminate restricts the permanent exposition of PVT absorber to temperatures above $90^{\circ} \mathrm{C}$ because of its corrosiveness under high temperature exposition [4]. It has been proved that the long-term thermal load at such temperature levels results in decomposition of EVA to acetic acid which causes the corrosion of PV cells contacts, delamination, and also degradation of the encapsulation layer transparency [5-7].

High stagnation temperature of the glazed PVT collector leads to searching in the new materials for encapsulation of the strings of PV cells. A novel glazed PVT collector concept based on PV laminate with polysiloxane gel has been developed at Czech Technical University in Prague. Polysiloxane gel instead of EVA lamination compound offers several important advantages, mainly the high temperature resistance and high transparency. A developed glazed PVT collector is described, and results of testing are presented 
and used for the performance-economic analysis to give an answer to basic questions concerning the possible competitiveness of glazed PVT collector. The maximum market price for the PVT liquid collector concepts has been determined for combined solar heat and power supply for multifamily building in order to be competitive when compared with conventional separate PV and PT collectors installation at given boundary conditions (building heat and electricity load, energy prices, and prices of conventional solar collectors) in different climates of Europe.

\section{Glazed PVT Collector Concept with Polysiloxane Encapsulation}

Silicone polymers (polysiloxanes) are more suitable candidates for application as PV encapsulant for glazed PVT collectors than the EVA material. Polysiloxane gel offers several important advantages like large range of operation temperature (from -60 to $+250^{\circ} \mathrm{C}$ ), high transparency for solar radiation (even higher compared to EVA in solar wavelength region), compensation of thermal dilatation stresses due to low modulus of elasticity (permanent gel), high physical adhesion to semiconductors, glass, and most other materials without use of sublayers, and good heat transfer from PV cells to heat exchanger due to higher thermal conductivity [7-9]. Polysiloxane laminate thus opens the application potential especially for the glazed PVT collectors development. Silicone gel encapsulation machine available at University Centre for Energy Efficient Buildings (Czech Technical University, CTU) enables fabricating the solar PVT collector prototypes. The encapsulation technology is based on low vacuum dosing of the gel into the gap between glass pane and flat heat exchanger with immersed strings of PV cells. The encapsulation process is carried out at room temperature. This fact brings a clear advantage for future production.

Strong accent has been put also on simplicity of the glazed PVT collector design and fabrication by means of reduced number of elements to compose the collector. A new concept of solar glazed PVT collectors has been introduced. Double glazing with a gap between glass panes $20 \mathrm{~mm}$ filled with argon has been used for encapsulation of PV cells with the iron heat exchanger by polysiloxane gel (see Figure 1). Two designs have been tested so far. Nonselective glazed PVT collector has been fabricated from double glazing with uncoated solar glass panes and double glazing with a low emissivity coating has been used for the spectrally selective PVT collector. Today low-e coatings have high transparency for visible range but unfortunately significantly reduced transmittance for near infrared region of solar radiation spectrum. The presented glazed selective PVT collector has been made with commercially widely available low-e coating with no optimization of the emissivity and transparency. Fully wetted heat exchanger has been used for both PVT collectors. Aperture area of the glazed PVT collectors was $0.67 \mathrm{~m}^{2}$. In total only $4 \times 6$ polycrystalline $\mathrm{PV}$ cells at size $156 \times 156 \mathrm{~mm}$ have been used due to given size of absorber. Aperture area has been covered to $87 \%$ by PV cells (packing

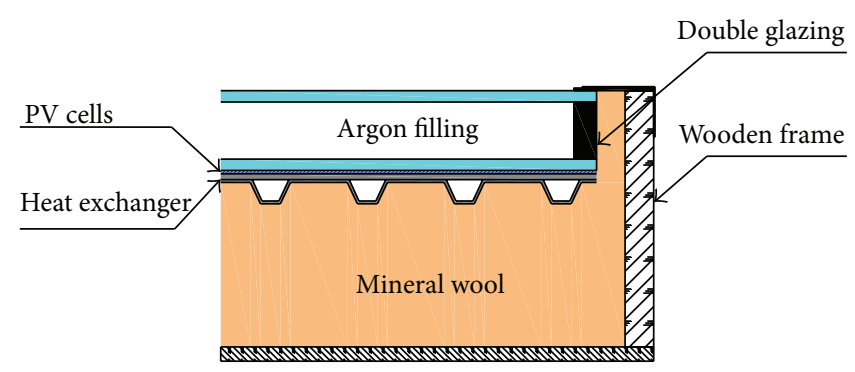

FIGURE 1: Layout of the investigated glazed PVT collectors.

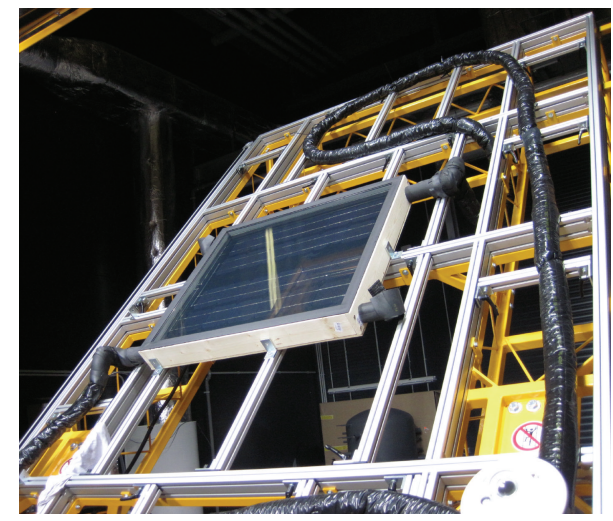

FIGURE 2: Glazed nonselective PVT collector at indoor test stand.

factor). Absorber has been insulated by $40 \mathrm{~mm}$ of mineral wool on the back and $10 \mathrm{~mm}$ of EPDM foam at the edge side and put into wooden frame.

Glazed solar PVT collector prototypes have been tested under conditions of artificial sun at University Centre for Energy Efficient Buildings in Bustehrad (see Figure 2). Tests have been performed in accordance with EN 12975 for the open circuit mode and under MPPT electric load conditions.

Figure 3 shows the comparison of thermal performance characteristics for glazed PVT prototypes with siloxane gel lamination (selective, nonselective) and state-of-the-art solar photothermal (PT) selective collector. All characteristics resulted from the experimental testing. Comparison has confirmed the excellent properties of polysiloxane gel encapsulation. High zero-loss efficiency for nonselective alternative of PVT prototype indicates the good heat transfer from PV absorber into heat transfer liquid and high transparency of the polysiloxane layer. On the other side, the high radiative heat loss reduces the thermal performance of the nonselective PVT collector at high temperatures. Results for selective PVT collector prototype have confirmed the assumption of the high reflection losses in the near infrared radiation region due to the low-e coating applied to absorber laminate glass. In any case, the results revealed the field for further improvements of the glazed PVT collector. Main effort should be concentrated on optimized low-e coating with high solar transmittance but low emissivity for near infrared region. Such coatings with transmittance $86 \%$ and emissivity $30 \%$ are already in the market and will be used further for the final glazed PVT concept [10]. Thermal efficiency for the new glazed selective 


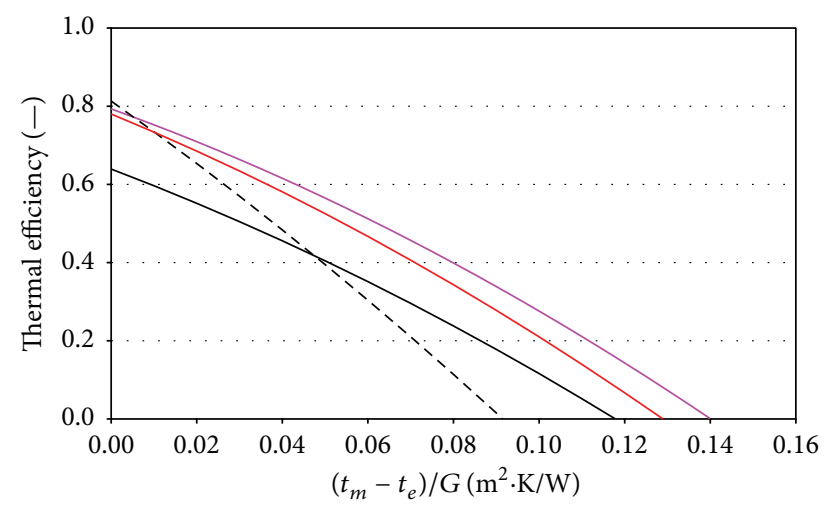

$$
\begin{aligned}
& \text { - Conventional solar photothermal collector } \\
& \text {-- - Nonselective PVT collector (tested) } \\
& \text { — Selective PVT collector (tested) } \\
& \text { — Selective PVT collector (modelled) }
\end{aligned}
$$

FIGURE 3: Comparison of thermal efficiency characteristics for glazed PVT collectors (open circuit) under development and stateof-the-art photothermal collector.

PVT collector has been modelled with a detailed glazed PVT model [11]. Results for open electric circuit mode are added into graph in Figure 3. The characteristics are shown in dependency on the difference between the mean fluid temperature $t_{m}$ and ambient temperature $t_{e}$ reduced by solar irradiance $G\left[\mathrm{~W} / \mathrm{m}^{2}\right]$.

\section{Performance-Economic Analysis of PVT Application for Multifamily Building}

Today research and development of solar energy products have to focus on competitive solutions. It is quite problematic to develop the components which are sophisticated and efficient on the one side but with the payback time beyond the lifetime. The development and commercialization of the PVT collector design requires the performance and economic information to analyse the competitiveness at the potential market. The maximum competitive price of the PVT collector and realistic production costs can indicate if the glazed PVT concept is viable or not or at which boundary conditions (e.g., energy prices). Therefore, the target of the performance and economic analysis presented here was to find the competitive specific price range for given concepts of solar hybrid PVT collectors. The investigated alternatives of solar hybrid PVT collectors are

(i) unglazed PVT collector in the quality available on the market,

(ii) glazed nonselective PVT collector with the siloxane gel encapsulation,

(iii) glazed selective PVT collector with the siloxane gel encapsulation.

Thermal performance of the analysed hybrid PVT collector concepts is represented by thermal efficiency characteristics in MPPT (maximum power point tracking) operation;

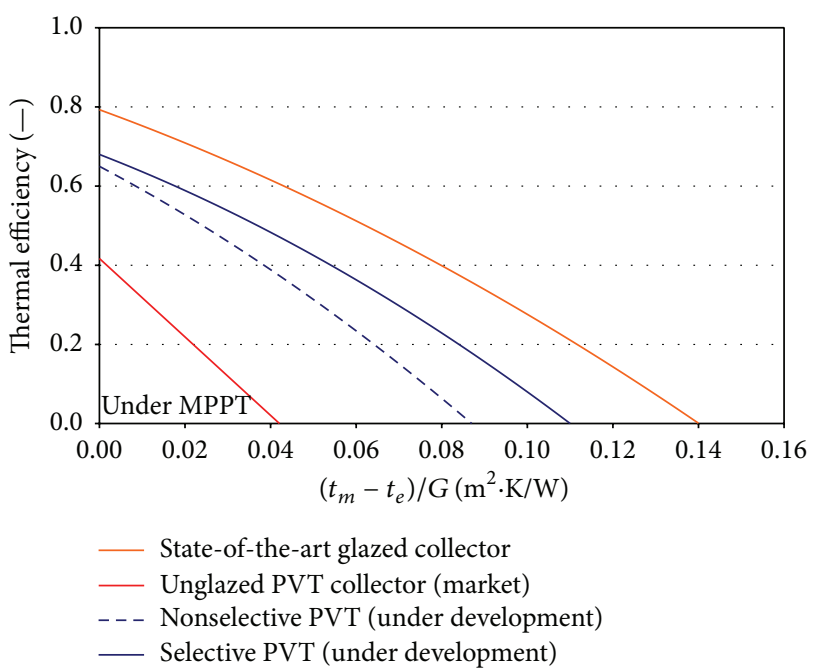

FIGURE 4: Thermal efficiency characteristics of PVT collectors used in analysis (under MPPT electric load).

see Figure 4. The characteristics have been derived from the testing and modelling of given PVT concepts assuming uniform use of polycrystalline PV cells with efficiency 15\% (standard testing conditions) and power temperature coefficient $0.45 \% / \mathrm{K}$. The same PV cells have been considered also for conventional PV module performance modelling. Figure 4 shows also the thermal efficiency characteristic for state-of-the-art solar thermal collector with spectrally selective surface used for modelling of conventional glazed solar photothermal collector applied in the performance analysis.

The analysis has been performed for combined solar heat and power system for multifamily residential building. The performance and economic analyses are based on the solar energy system with the combined heat and electricity production for a residential building with 45 flats and 100 occupants. Solar heat is used for DHW preparation, and solar electricity is used for the building appliances load. Heat demand for hot water use in the building is $96 \mathrm{MWh} / \mathrm{a}$. Electricity demand for the building is $113 \mathrm{MWh} / \mathrm{a}$. Analyses have been performed for four different climate zones in Europe with different annual solar irradiation sum: Prague $\left(1096 \mathrm{kWh} / \mathrm{m}^{2} \cdot \mathrm{a}\right)$, Stockholm $\left(1206 \mathrm{kWh} / \mathrm{m}^{2} \cdot \mathrm{a}\right)$, Milan $\left(1367 \mathrm{kWh} / \mathrm{m}^{2} \cdot \mathrm{a}\right)$, and Marseille $\left(1760 \mathrm{kWh} / \mathrm{m}^{2} \cdot \mathrm{a}\right)$.

The solar system with hybrid PVT liquid collectors of different design concepts has been compared with conventional solar heat and power system combining the state-of-theart solar photothermal collectors and photovoltaic modules with identical polycrystalline cells as used in hybrid PVT collectors. Available solar collector field area $100 \mathrm{~m}^{2}$ on the building roof is the total collector area for all systems in the analyses. Conventional solar PV and PT system is considered in 5 alternatives differing in the percentage ratio of PV and PT solar collector area applied. The alternatives are

(i) $100 \% \mathrm{PV}\left(100 \mathrm{~m}^{2}\right.$ of PV collector, $0 \mathrm{~m}^{2}$ of PT collector), 


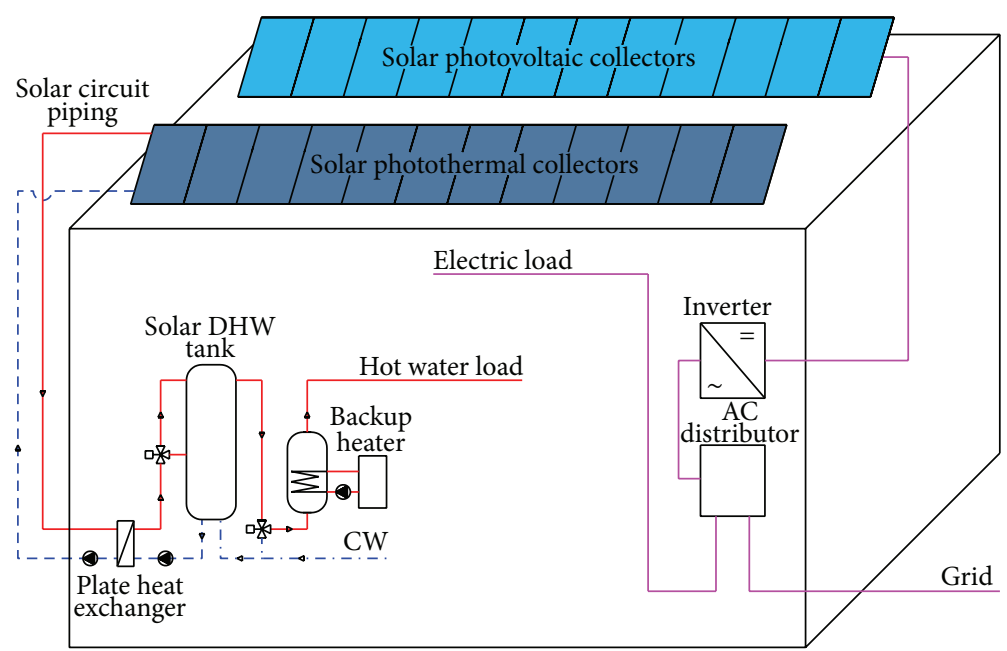

FIGURE 5: Simplified scheme of the considered solar energy system for block of flats.

(ii) $75 \% \mathrm{PV}-25 \% \mathrm{PT}\left(75 \mathrm{~m}^{2}\right.$ of PV collector, $25 \mathrm{~m}^{2}$ of PT collector),

(iii) $50 \%$ PV-50\% PT ( $50 \mathrm{~m}^{2}$ of PV collector, $50 \mathrm{~m}^{2}$ of PT collector),

(iv) $25 \% \mathrm{PV}-75 \% \mathrm{PT}\left(25 \mathrm{~m}^{2}\right.$ of PV collector, $75 \mathrm{~m}^{2}$ of PT collector),

(v) $100 \%$ PT $\left(0 \mathrm{~m}^{2}\right.$ of PV collector, $100 \mathrm{~m}^{2}$ of PT collector).

Solar heat and power systems have been modeled in TRNSYS environment with use of the available models for unglazed PVT collector [12] and glazed PVT collector [11]. Simplified scheme of the solar energy system is shown in Figure 5. Solar thermal part of the investigated system variants consists of several main components: solar collectors with slope $45^{\circ}$ and orientation to south, insulated pipes of collector circuit, heat exchanger, and insulated solar DHW storage tank. Parameters of the main components for the solar thermal systems alternatives are considered dependent on collector field area considered in the different variants. Dimension of the collector circuit pipes is based on specific mass flow rate $15 \mathrm{~kg} / \mathrm{h} \cdot \mathrm{m}^{2}$ of collector area (low flow solar system). Pipes length of solar collector circuit in outdoor environment is $130 \mathrm{~m}$, and length of pipes inside the building is $30 \mathrm{~m}$. Solar tank volume has been determined from specific value $50 \mathrm{~L} / \mathrm{m}^{2}$ of collector area. Solar plate heat exchanger has the efficiency $85 \%$. PV power system is a conventional grid-on system with DC/AC inverter. Total system losses are considered $10 \%$. Whole PV electricity production is assumed to be consumed for the building appliances load.

Results of TRNSYS simulations for individual alternatives for Prague climate (moderate climate) and Marseille (warm climate) are compared in Figure 6. Comparison shows the general advantage of the glazed hybrid PVT collectors in energy yields. Despite the lower effectivity for heat production compared to conventional solar thermal collector and lower effectivity for electricity production compared to conventional PV modules, the glazed selective PVT collector results in higher combined energy gains when compared with separate PV and PT combination with different ratio between the technologies. Nonselective PVT collector shows heat production lower than conventional state-of-the-art solar photothermal collector in the conditions of Prague; however, the significant portion of energy produced is the electricity with better usability compared to heat. Marseille conditions are better and total energy production of nonselective glazed PVT collector is even higher than for conventional thermal collector. Unglazed PVT collector shows a low thermal performance in the domestic hot water application especially in the moderate climate of Prague.

To define the competitive price for investigated PVT collectors on the market, the following economic conditions have been set. Inputs for the economic calculations are the heat and electricity price and costs for solar PT and PV collectors and the system costs. Electricity price for households in Europe varies between 8 eurocents/kWh and 30 eurocents/kWh depending on the region [13]. Similarly, the range of heat price is quite wide between 4 eurocents/kWh and 16 eurocents/kWh dependent on the fuel and technology used for heat production and local legislation, for example, specific taxes on fossil fuels [14]. Electricity price of 16 eurocents/kWh and heat price of 8 eurocents/kWh common in Germany with the largest solar systems market in Europe have been used for the economic analysis.

Costs for solar energy systems are given by solar thermal collectors costs, solar PV modules costs, and the costs for the rest of the system (piping, storage, control, cables, invertor, support constructions, etc.). Simplification has been used in the idea that solar collectors are always considered representing the $50 \%$ of total system costs in both PV and PT systems. Solar collector costs are considered $120 \mathrm{EUR} / \mathrm{m}^{2}$ for photovoltaic polycrystalline modules and $350 \mathrm{EUR} / \mathrm{m}^{2}$ for the state-of-the-art spectrally selective solar thermal collectors. The same costs have been considered as the costs for the rest of the system. 


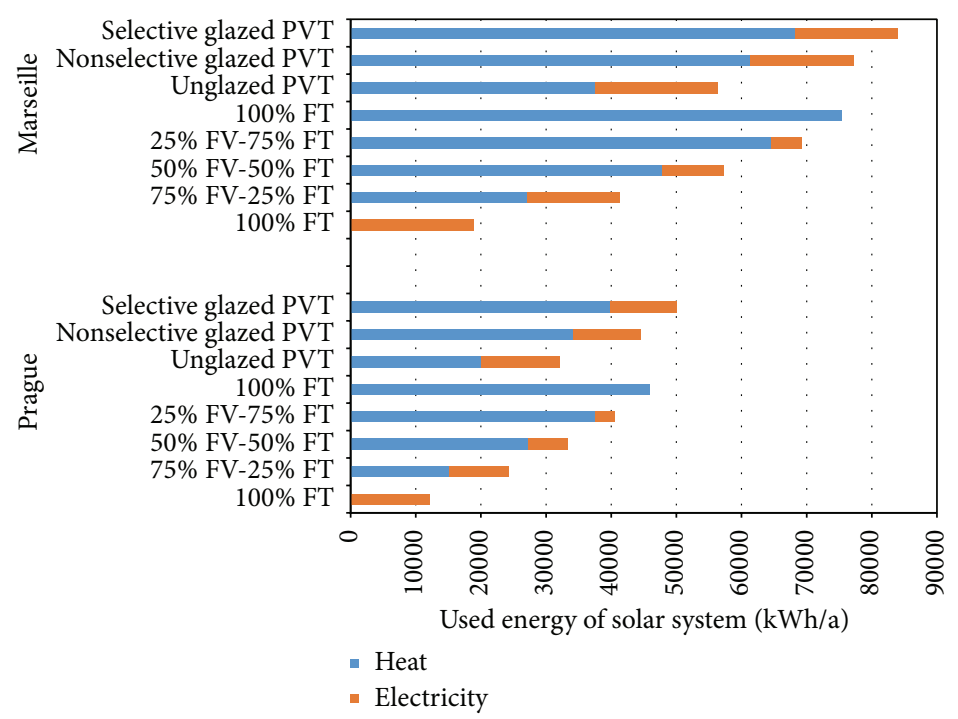

FIGURE 6: Comparison of energy gains for different PVT collector designs and conventional combination.

The competitive specific price for given hybrid PVT collector alternative has been derived from the balance of investment costs and operation costs for 20 years lifetime period for conventional PV/PT system and the hybrid PVT system. The specific collector price is derived from the conditions that total lifetime costs of hybrid PVT system and combined conventional PV and PT system are equal. Interest rate is considered equal to energy price increase, assuming that both are at $5 \%$ level. Competitive specific price $\left(\mathrm{EUR} / \mathrm{m}^{2}\right)$ for hybrid PVT collectors has been calculated from the results of performance analyses (energy savings) and the economic inputs presented above. Each solar hybrid PVT system has been economically compared with 5 different conventional PV and PT system alternatives (ratio between PV and PT collector area). Results are shown in Figures 7-9 for investigated alternatives of PVT collectors.

Graph in Figure 7 shows the competitive specific price for unglazed PVT collectors available at today European market. While market price for unglazed PVT collector ranges today between 300 and $500 \mathrm{EUR} / \mathrm{m}^{2}$, competitive price level is much lower and thus the unglazed PVT collectors are not competitive with conventional combination of photothermal and photovoltaic collectors even in southern Europe. Only the cheapest unglazed collector systems could compete with photovoltaic only or photothermal only systems. Unglazed PVT collectors are out of the competitive range for central and northern Europe due to the poor thermal performance. It could be stated that unglazed PVT collectors are not economically applicable for solar DHW systems and have a very limited application potential with their market price today.

The situation is better for the glazed PVT collectors. In the case of nonselective collectors the range of the competitive price is 300 to $500 \mathrm{EUR} / \mathrm{m}^{2}$ for southern Europe but significantly lower for central and northern Europe (see Figure 8). The target technology of the glazed selective PVT

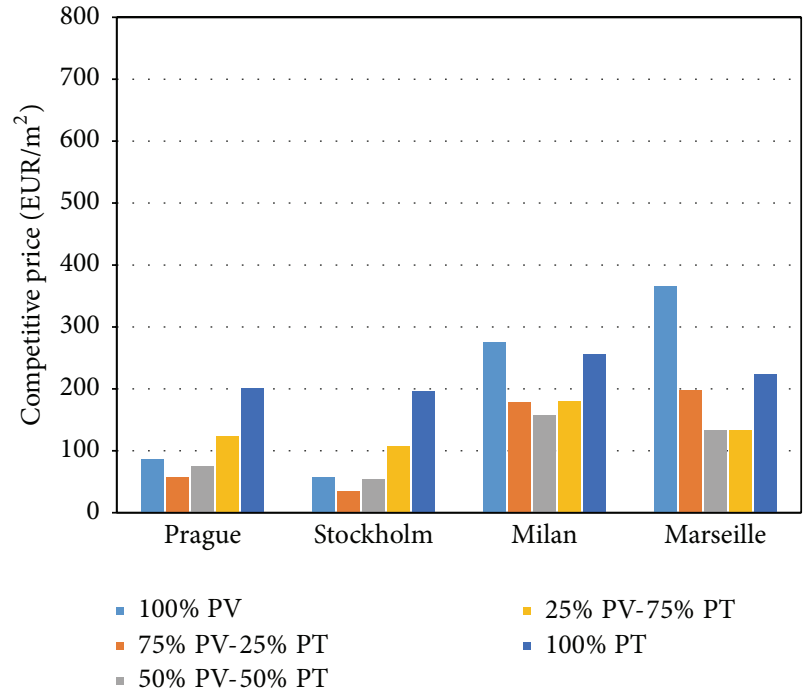

FIGURE 7: Competitive specific price of unglazed hybrid PVT collector.

collectors ranges between 300 and $400 \mathrm{EUR} / \mathrm{m}^{2}$ for central and northern Europe and between 400 and $600 \mathrm{EUR} / \mathrm{m}^{2}$ for southern Europe (see Figure 9). These figures are much more optimistic with respect to conservative inputs for economic analysis (low increase of energy prices and high interest rate for residential application) and show the glazed selective PVT collector as a viable concept.

\section{Conclusion}

The new concept of glazed solar PVT collector with polysiloxane gel encapsulation of PV cells has been developed and prototypes were tested and evaluated. Experimental work has confirmed the excellent optical and thermal performance 


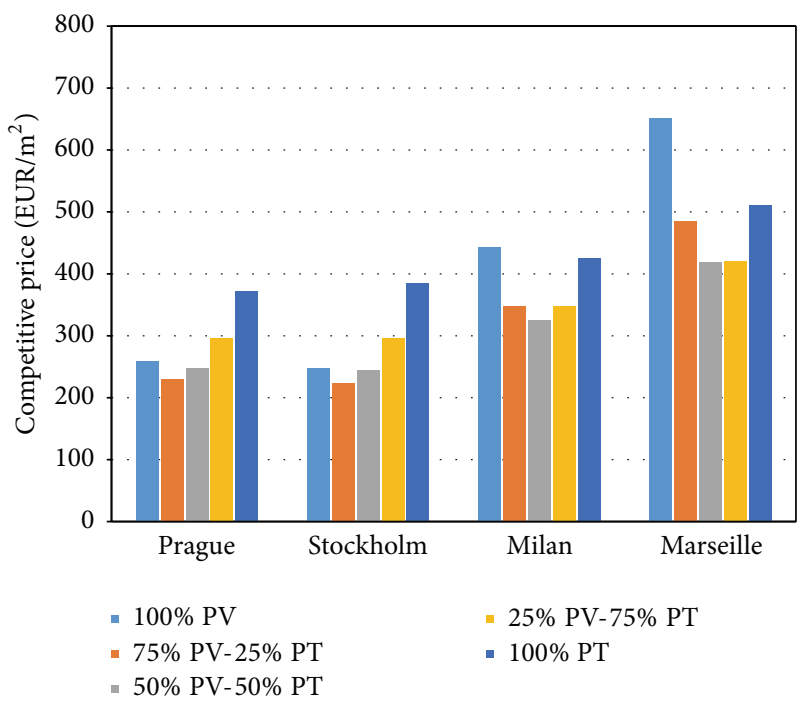

FIGURE 8: Competitive specific price of glazed nonselective hybrid PVT collector.

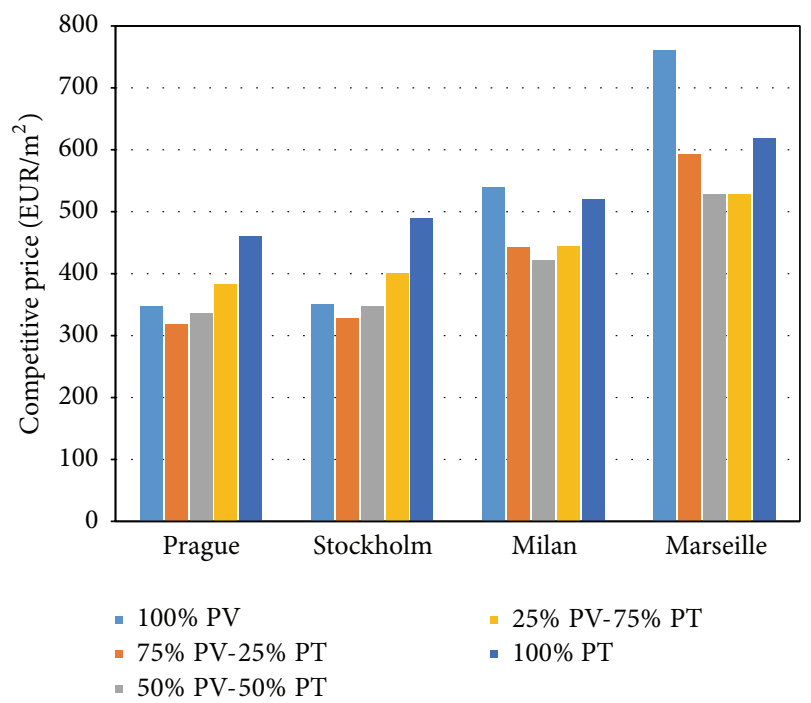

FIGURE 9: Competitive specific price of glazed selective hybrid PVT collector.

features of polysiloxane laminate application for solar PVT absorbers. Further improvements will be done in glazed PVT collector design using the advanced highly transparent low-e glazing. To evaluate the commercial potential of the different PVT collector concepts, the competitive market price has been subjected to performance and economic analysis for combined solar heat and power system for given residential building. It has been shown that unglazed PVT collectors in the field of common solar DHW applications cannot be competitive with the conventional solar thermal collector and photovoltaic modules combination. The resulted competitive price figures for the presented glazed selective PVT collector which is under development have proved the viability of the new concept.

\section{Conflict of Interests}

The authors declare that there is no conflict of interests regarding the publication of this paper.

\section{Acknowledgments}

The research leading to these results has received funding from the European Union's Seventh Framework Programme FP7/2007-2011 under Grant Agreement no. 282825, Acronym MacSheep. The paper has been supported by European Union project OP VaVpI no. CZ.1.05/2.1.00/03.0091, University Centre for Energy Efficient Buildings.

\section{References}

[1] H. A. Zondag, D. W. de Vries, W. G. J. van Helden, R. J. C. van Zolingen, and A. A. van Steenhoven, "The yield of different combined PV-thermal collector designs," Solar Energy, vol. 74, no. 3, pp. 253-269, 2003.

[2] T. T. Chow, G. Pei, K. F. Fong, Z. Lin, A. L. S. Chan, and J. Ji, "Energy and exergy analysis of photovoltaic-thermal collector with and without glass cover," Applied Energy, vol. 86, no. 3, pp. 310-316, 2009.

[3] P. Dupeyrat, C. Ménézo, M. Rommel, and H.-M. Henning, "Efficient single glazed flat plate photovoltaic-thermal hybrid collector for domestic hot water system," Solar Energy, vol. 85, no. 7, pp. 1457-1468, 2011.

[4] A. Parretta, M. Bombace, G. Graditi, and R. Schioppo, "Optical degradation of long-term, field-aged c-Si photovoltaic modules," Solar Energy Materials \& Solar Cells, vol. 86, no. 3, pp. 349-364, 2005.

[5] H. A. Zondag and W. G. J. van Helden, "Stagnation temperature in PVT collectors," in Proceedings of the PV in Europe-From PV Technology to Energy Solutions Conference and Exhibition, Rome, Italy, October 2002.

[6] H. A. Zondag, "Flat-plate PV-Thermal collectors and systems: a review," Renewable and Sustainable Energy Reviews, vol. 12, no. 4, pp. 891-959, 2008.

[7] V. Poulek, D. S. Strebkov, I. S. Persic, and M. Libra, “Towards 50 years lifetime of PV panels laminated with silicone gel technology," Solar Energy, vol. 86, no. 10, pp. 3103-3108, 2012.

[8] V. Poulek, M. Libra, V. Jirka, and I. Persic, Polysiloxane Gel Lamination Technology for Solar Panels and Rastered Glazing, ILSA, Praha, Slovakia, 2013.

[9] T. Matuska, V. Jirka, and V. Poulek, "Use of polysiloxane gel as laminate for solar PVT collectors," in Proceedings of the International Conference on Solar Energy and Buildings (EuroSun '14), Aix-les-Bains, France, September 2014.

[10] F. Glovanneti, S. Föste, N. Ehrmann, and G. Rockendorf, "High transmittance, low emissivity glass covers for flat plate collectors: applications and performance," Energy Procedia, vol. 30, pp. 106-115, 2012.

[11] N. Pokorny, T. Matuska, and B. Sourek, "Modelling of glazed liquid PV-T collector with use of detail model," in Proceedings of the Building Simulation International Conference (BS '15), Hyderabad, India, 2015.

[12] M. Stegmann, E. Bertram, G. Rockendorf, and S. Janßen, "Model of an unglazed photovoltaic thermal collector based 
on standard test procedures," in Proceedings of the 30th ISES Biennial Solar World Congress (SWC '11), pp. 2639-2647, Kassel, Germany, September 2011.

[13] Eurostat Electricity prices for household consumers, 2014, http://epp.eurostat.ec.europa.eu.

[14] Euroheat \& Power District heating and cooling statisticscountry by country survey, 2014, http://www.euroheat.org/. 

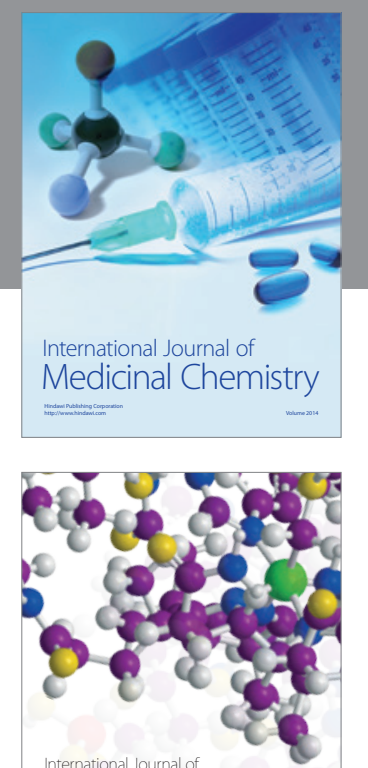

\section{Carbohydrate} Chemistry

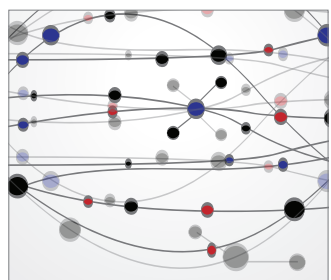

The Scientific World Journal
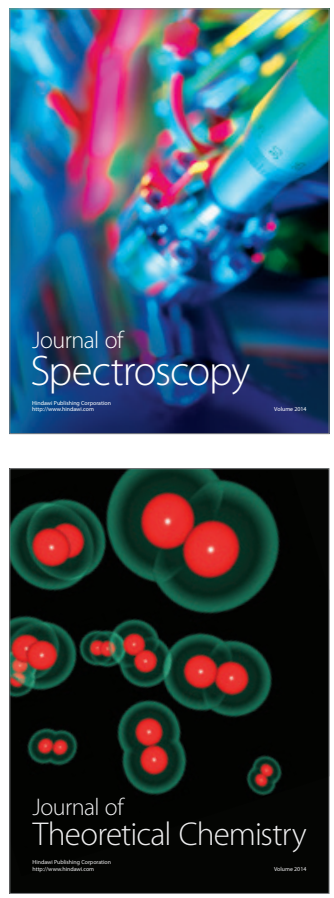
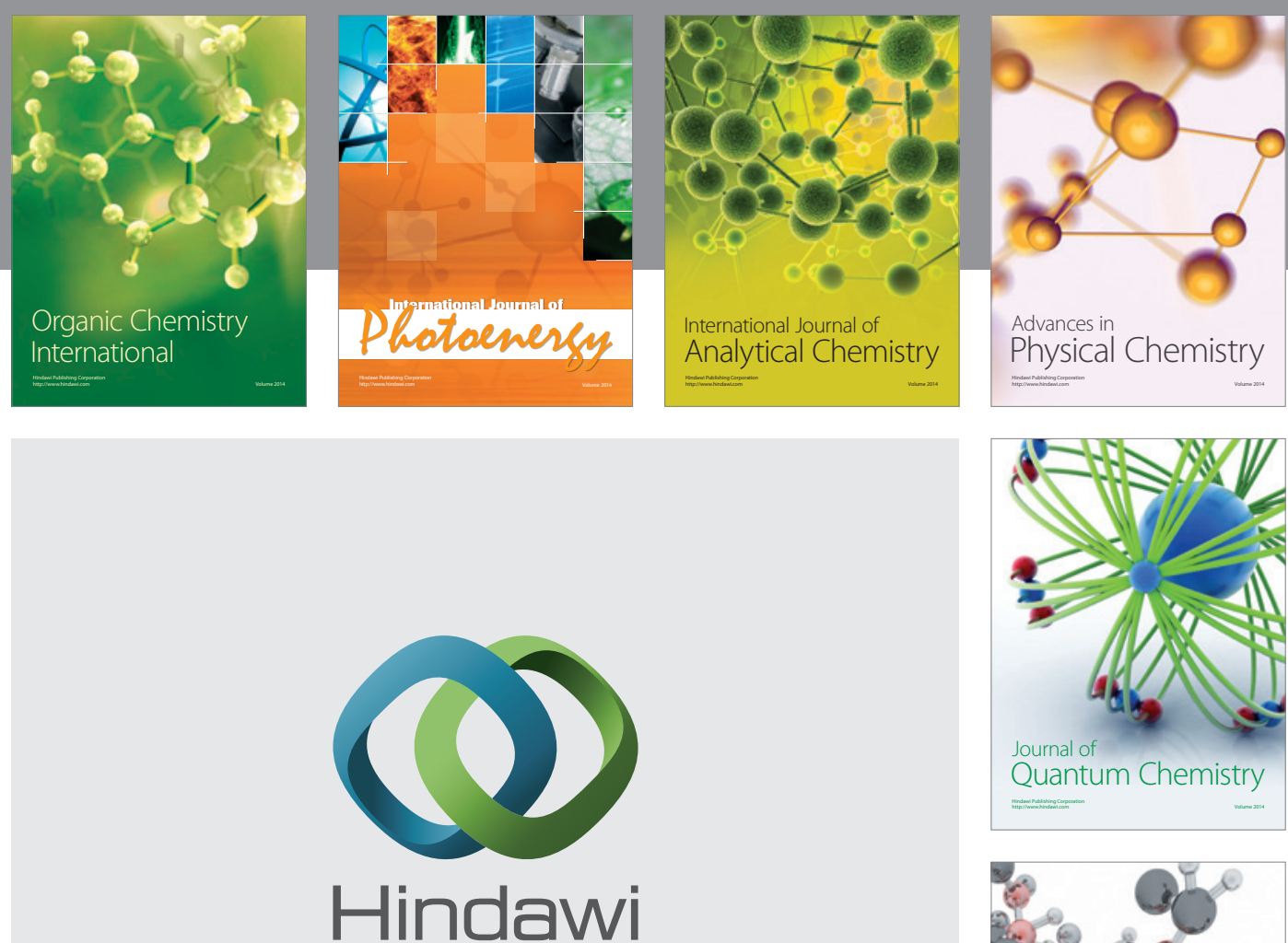

Submit your manuscripts at

http://www.hindawi.com

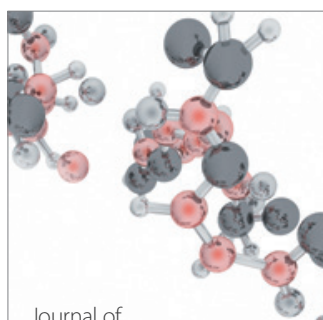

Analytical Methods

in Chemistry

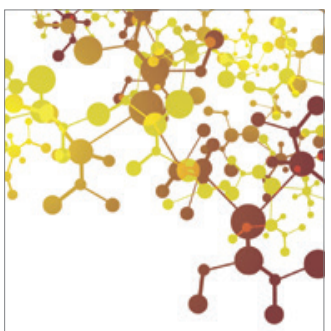

Journal of

Applied Chemistry

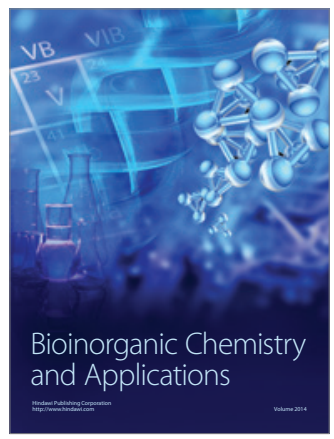

Inorganic Chemistry
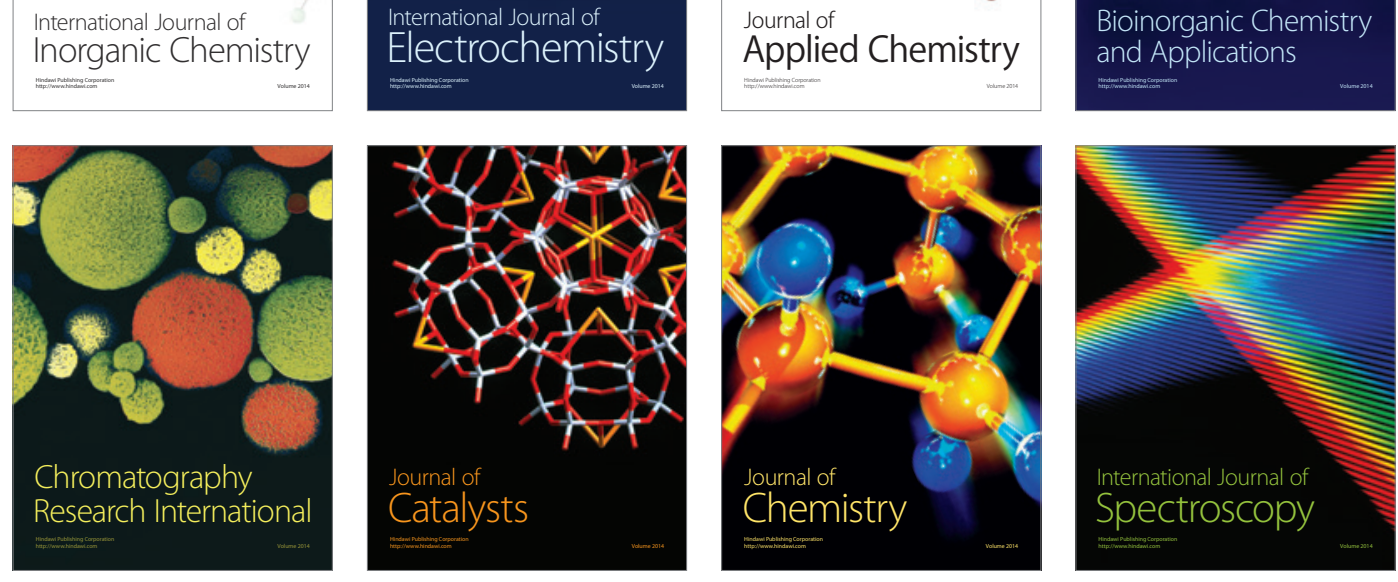